\title{
Determination of Cobalt, Iron, and Nickel in High-Purity Silicon by High-Resolution Continuum Source Graphite Furnace Atomic Absorption Spectrometry Employing Solid Sample Analysis
}

\author{
Marcos André Bechlin ${ }^{a}$, Ariane Isis Barros ${ }^{a}$, Diego Victor Babos ${ }^{a}$, Edilene Cristina Ferreira ${ }^{a}$, \\ and José Anchieta Gomes Neto ${ }^{a}$,* \\ a UNESP - Univ. Estadual Paulista, Analytical Chemistry Department \\ Rua Prof. Francisco Degni, 55, Quitandinha, 14800-060, Araraquara - SP, Brazil
}

\section{INTRODUCTION}

Renewable energy and energy efficiency may be considered the pillars of sustainable energy, and they are now entering global markets as a result of research and development $(1,2)$. The production of pure silicon used as a raw material by the solar photovoltaic and microelectronic industries has increased in order to supply the rapid-growth markets (3). The presence of impurities in solar-grade silicon (SoG-Si) and electronicgrade silicon (EG-Si) may significantly reduce the efficiency of semiconductor devices, solar cells, integrated circuits, etc. (4). Depending on the concentration of $\mathrm{Co}, \mathrm{Ni}, \mathrm{Cr}$, and $\mathrm{Fe}$, these elements may generate recombination centers, which will consume electrons produced by the photovoltaic effect in solar cells $(5,6)$. These devices may have their efficiency reduced by about $50 \%$ due to the presence of these elements (4). Thus, rigid quality control of the SoG-Si and EG-Si materials is very important.

Among the main spectroscopic techniques employed for elemental determinations, most use conventional sample introduction systems for the solutions. The conversion of SoG-Si and EG-Si solid materials into solutions is usually done by wet digestions involving mixtures of hydrofluoric acid with strong acids at high temperature (7). These

* Corresponding author.

:E-mail: anchieta@iq.unesp.br

Tel: +551633019611

\section{ABSTRACT}

This paper describes the development of analytical methods for the determination of cobalt, iron, and nickel in pure silicon for photovoltaic and electronics applications based on solid sampling (SS) coupled to a high-resolution continuum source graphite furnace atomic absorption spectrometer (HR-CS GFAAS). Samples were also analyzed by line-source flame atomic absorption spectrometry (LS FAAS) as a comparative technique after acid microwave-assisted digestion. Cobalt, Fe, and Ni were determined in samples of solargrade silicon (SoG-Si) and electronic-grade silicon (EG-Si) by SS HR-CS GFAAS and LS FAAS. A paired $t$-test at a $95 \%$ confidence level showed that the SS HR-CS GFAAS methods achieve similar results to those obtained by LS FAAS. The relative standard deviations $(n=12)$ for a sample containing $7.80 \mathrm{mg} \mathrm{kg}^{-1} \mathrm{Co}, 36.2 \mathrm{mg} \mathrm{kg}^{-1}$ $\mathrm{Fe}$, and $228.5 \mathrm{mg} \mathrm{kg}^{-1} \mathrm{Ni}$ were $6.4 \%$ for $\mathrm{Co}, 6.1 \%$ for $\mathrm{Fe}$, and $1.0 \%$ for Ni for SS HR-CS GFAAS. For the SS HR-CS GFAAS, the limits of detection were $0.39 \mathrm{mg} \mathrm{kg}^{-1}$ $\mathrm{Co}, 1.14 \mathrm{mg} \mathrm{kg}^{-1} \mathrm{Fe}$, and $5.71 \mathrm{mg}$ $\mathrm{kg}^{-1} \mathrm{Ni}$. Accuracy was also checked by the analysis of highpurity silica spiked with $\mathrm{Co}, \mathrm{Fe}$, and $\mathrm{Ni}$, and the recoveries were at $94.3-97.1 \%(\mathrm{Co}), 86.7-109 \%$ (Fe), and $88.4-98.9 \%(\mathrm{Ni})$.

procedures are arduous, time-consuming, vulnerable to sample contamination and analyte losses, involve high consumption of energy, use large quantities of hazardous reagents, and generate substantial amounts of waste. These disadvantages may be avoided by using direct solid sample analysis, an environmentally friendly method operating according to the principle of green chemistry (8).

Solid sampling (SS) has been explored for the analysis of highpurity silicon by total reflection $\mathrm{X}$-ray fluorescence spectroscopy (9), laser-induced breakdown spectroscopy (10), glow discharge mass spectrometry (11), neutron activation analysis (12), secondary ion mass spectrometry (13), and laserablation inductively coupled plasma mass spectrometry (14). These techniques are fast, sensitive and accurate, but acquisition and maintenance costs are relatively higher than other procedures such as graphite furnace atomic absorption (GFAAS).

High-resolution continuum source graphite furnace atomic absorption spectrometry coupled to solid sampling (SS HR-CS GFAAS) brought new possibilities for elemental spectrometric analyses (15) due to the ability to correct structured background using leastsquares background correction (LSBC), to measure the spectral environment in high resolution, furnish higher signal-to-noise ratios than those provided by line sources, to sum the absorbance measurement around the line core, or to sum the absorbance for different lines, to extend the linear working range by measuring at alternative lines, and to integrate auto- 
matic solid sampler and microbalance which may reduce errors caused by manual operations (16, 17). The SS HR-CS GFAAS method is efficiently employed for the analysis of difficult samples such as polymers (18), glass (19), coal (20), automotive catalyst (21), and others. However, little attention has been given to the solid sampling method to analyze SoG-Si and EG-Si materials.

Considering the above, this work deals with the development of analytical methods for the determination of $\mathrm{Co}, \mathrm{Fe}$, and $\mathrm{Ni}$ contaminants in So-GSi and EG-Si.

\section{EXPERIMENTAL}

\section{Instrumentation}

Atomic absorption measurements were carried out using an Analytik Jena ContrAA 700 graphite furnace atomic absorption spectrometer (Jena, Germany), equipped with a short-arc Xenon lamp operated in "hot-spot" mode as a continuum radiation source, a high-resolution double monochromator, and a charge-coupled device (CCD) detector. Measurements were done at the $252.136 \mathrm{~nm}$ (Co), $305.760 \mathrm{~nm}(\mathrm{Ni})$, and $305.909 \mathrm{~nm}$ (Fe) lines. The lines of $\mathrm{Ni}$ and $\mathrm{Fe}$ were within the same spectral window, so they were measured simultaneously. The integrated peak absorbance (peak volume selected absorbance) was equivalent to 3 pixels $(\mathrm{CP} \pm 1$; $\mathrm{CP}$ : central pixel corresponding to the center of the line). Solid sampling graphite tubes without a dosing hole, pyrolytically coated, and transversely heated were used throughout this work. The samples were weighed directly onto solid sampling platforms using a WZ2PW microbalance (Sartorius, Göttingen, Germany) with an accuracy of $0.001 \mathrm{mg}$. The platforms were inserted into the graphite tubes using a SSA 600 solid autosampler (Analytik Jena). High purity argon (99.999\%, White Mar- tins, Sertãozinho, Brazil) was used as the purge and protection gas. The graphite furnace heating programs for the determination of Co, $\mathrm{Ni}$, and Fe are presented in Table I.

A PerkinElmer ${ }^{\circledR}$ AAnalyst $^{\mathrm{TM}} 100$ line source flame atomic absorption spectrometer (PerkinElmer, Inc., Shelton, CT, USA), equipped with a deuterium-lamp background correction system, was used as the comparative technique. Hollow cathode lamps for $\mathrm{Co}, \mathrm{Fe}$, and Ni were operated at the 25,30 , and $25 \mathrm{~mA}$ current, respectively. Absorbance measurements at $240.7 \mathrm{~nm}$ (Co), $248.3 \mathrm{~nm}(\mathrm{Fe})$, and $232.0 \mathrm{~nm}(\mathrm{Ni})$ using a 3-s integration time and $0.2 \mathrm{~nm}$ spectral bandwidth were used. Air and acetylene flow rates for all elements were established at a proportion of $4: 2$ oxidant/fuel. The aspiration flow rate and observation height were fixed at $5.0 \mathrm{~mL}$ $\mathrm{min}^{-1}$ and $7 \mathrm{~mm}$, respectively.

An Anton Paar Multiwave ${ }^{\circledR}$ microwave oven (Graz, Austria), equipped with six Teflon ${ }^{\circledR}$ flasks, was used for sample digestion.

\section{Reagents, Standards, and Samples}

All solutions were prepared using high purity water (18.2 M $\Omega$ $\mathrm{cm}$ resistivity) obtained from a Rios $5^{\circledR}$ reverse osmosis system and a Milli-Q ${ }^{\circledR}$ Academic ${ }^{\circledR}$ deionizer (Milli-

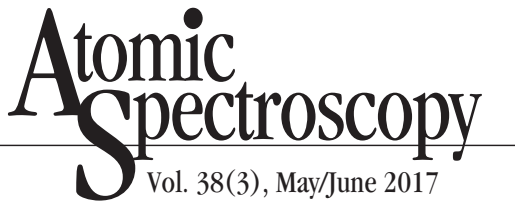

pore Corporation, Bedford, NY, USA). Suprapur ${ }^{\circledR}$ nitric acid (Merck Darmstadt, Germany) was used for preparing the solutions. Hydrofluoric acid (Merck, Darmstadt, Germany) and hydrogen peroxide (Panreac, Barcelona, Spain) were used for wet digestion.

Working standard solutions containing $0.1 \mathrm{mg} \mathrm{L}^{-1} \mathrm{Co}, 1.0 \mathrm{mg} \mathrm{L}^{-1} \mathrm{Fe}$ and Ni were prepared by proper dilution of $1000 \mathrm{mg} \mathrm{L}^{-1} \mathrm{Co}, \mathrm{Fe}$, and Ni single stock standards (Specsol, São Paulo, Brazil) and acidified to $0.1 \%$ (v/v) $\mathrm{HNO}_{3}$.

For LS FAAS analysis, calibration curves in the range of $0.1-4.0$ $\mathrm{mg} \mathrm{L}^{-1} \mathrm{Co}, \mathrm{Fe}$, and Ni were prepared daily by properly dilution of the standard solutions.

Solar- and electronic-grade silicons were furnished by the laboratory of metallurgical processes of the Instituto de Pesquisas Tecnológicas do Estado de São Paulo (IPT) (São Paulo, Brazil). The samples were pulverized by scraping the silicon piece with a silicon carbide spatula. Accuracy was assessed by addition/recovery tests with 99\% $\mathrm{SiO}_{2}, 0.5-10 \mu \mathrm{m}$ (Sigma-Aldrich, USA).

For comparative purposes, the SoG-Si and EG-Si samples were digested according to the following procedure: a mass of $0.2 \mathrm{~g}$ of sam-

\section{TABLE I}

Optimized Heating Program for the Determination of Co, Fe, and Ni in SoG-Si by HR-CS GFAAS

\begin{tabular}{|c|c|c|c|c|}
\hline Step & $\begin{array}{c}\text { Temperature } \\
\left({ }^{\circ} \mathrm{C}\right)\end{array}$ & $\begin{array}{l}\text { Ramp } \\
\left({ }^{\circ} \mathrm{C} \mathrm{s}^{-1}\right)\end{array}$ & $\begin{array}{l}\text { Hold Time } \\
\text { (s) }\end{array}$ & 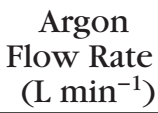 \\
\hline Drying 1 & 110 & 10 & 10 & 2.0 \\
\hline Drying 2 & 130 & 5 & 10 & 2.0 \\
\hline Pyrolysis & $1600^{\mathrm{a}}, 1300^{\mathrm{b}}$ & 50 & 15 & 2.0 \\
\hline Auto-zero* & $1600^{\mathrm{a}}, 1300^{\mathrm{b}}$ & 0 & 5 & 0 \\
\hline Atomization & $2400^{\mathrm{a}}, 2650^{\mathrm{b}}$ & $2400^{\mathrm{a}}, 3000^{\mathrm{b}}$ & $6^{\mathrm{a}}, 10^{\mathrm{b}}$ & 0 \\
\hline Cleaning & $2600^{\mathrm{a}}, 2700^{\mathrm{b}}$ & 500 & 5 & 2.0 \\
\hline
\end{tabular}

\footnotetext{
* Step to ensure that the atomization starts without the presence of argon
}

${ }^{\mathrm{a}}$ Conditions for $\mathrm{Co} ;{ }^{\mathrm{b}}$ Conditions for $\mathrm{Fe}$ and $\mathrm{Ni}$ determinations. 
ples was accurately weighed and transferred to the microwave flasks, followed by addition of $3.0 \mathrm{~mL}$ of concentrated nitric acid, $2.0 \mathrm{~mL}$ of concentrated hydrofluoric acid, and $1.0 \mathrm{~mL}$ of hydrogen peroxide. Then the optimized program of the microwave oven was run using (a) 15 minutes from 0 to $700 \mathrm{~W}$; (b) 15 minutes from 700 to $900 \mathrm{~W}$; (c) 15 minutes at $900 \mathrm{~W}$; and (d) 20 minutes at $0 \mathrm{~W}$ (ventilation). After digestion, the resulting solutions were transferred to digestion tubes and heated for 3 hours at 150 ${ }^{\circ} \mathrm{C}$ in the digestion heating block in order to eliminate the hydrofluoric acid. After cooling, the sample digests were transferred to $25-\mathrm{mL}$ volumetric flasks and made up to volume using distilled deionized water. The samples were digested in triplicate.

All glasses and polypropylene vessels were washed with Extran ${ }^{\circledR}$ detergent, soaked in 10\% (v/v) $\mathrm{HNO}_{3}$ for 24 hours, then rinsed abundantly with deionized water before use.

\section{Analytical Procedure}

The thermal behavior of the analytes was evaluated in a multivariate experiment using a factorial design $2^{\mathrm{n}}$, where $\mathrm{n}$ is the number of variables. In this work, a full $2^{3}$ factorial design was employed, the variables evaluated were the pyrolysis and atomization temperatures and the sample size. These variables were evaluated in two levels, minimum (-) and maximum (+). Table II lists the experimental matrix used for optimization, together with the minimum and maximum levels of each evaluated variable for $\mathrm{Co}, \mathrm{Fe}$, and $\mathrm{Ni}$.

The experimental data obtained from the factorial design were processed using the software Statgraphics Centurion XVI (Statpoint Technologies, Warrenton, VA, USA), generating a mathematical function whose maximization cor- responded to the ideal analytical conditions for each analyte (or for the joint monitoring of the analytes). The values of the three variables optimized by the factorial design were used in the graphite furnace heating program in subsequent experiments.

After establishing the heating programs, analytical curves were constructed in the $0.0-2.0 \mathrm{ng} \mathrm{Co}$, 0.0-15.0 ng Fe, and 0.0-3.5 ng Ni mass ranges, which were obtained by delivering different aliquots of $0.1 \mathrm{mg} \mathrm{L}^{-1} \mathrm{Co}, 1.0 \mathrm{mg} \mathrm{L}^{-1} \mathrm{Fe}$ and $\mathrm{Ni}$ standard solutions. The first point of the calibration curves, corresponding to $0.0 \mathrm{ng}$ (blank), was obtained by measuring the absorbance with an empty platform (concept of zero mass).

The possibility of using calibration with aqueous standards for direct solid sample analysis was evaluated by means of multiple effects of matrices by comparing the characteristic masses $\left(\mathrm{m}_{0}\right)$ and slopes of the calibration curves built up in $0.1 \%(\mathrm{v} / \mathrm{v}) \mathrm{HNO}_{3}$ and $\mathrm{SiO}_{2}$ media spiked with the analytes.

Accuracy was evaluated by means of addition/recovery tests. Masses of $0.15 \mathrm{mg} \mathrm{SiO}_{2}$ were spiked with 5.0 and $10.0 \mu \mathrm{L}$ of $0.1 \mathrm{mg} \mathrm{L}^{-1}$ Co, 3.0 and $5.0 \mu \mathrm{L}$ of $1.0 \mathrm{mg} \mathrm{L}^{-1} \mathrm{Fe}$ and Ni standard solutions in order to obtain final concentrations of $3.3 \mathrm{mg} \mathrm{kg}^{-1} \mathrm{Co}, 6.7 \mathrm{mg} \mathrm{kg}^{-1} \mathrm{Co}$, and $20 \mathrm{mg} \mathrm{kg}^{-1}$ and $33 \mathrm{mg} \mathrm{kg}^{-1} \mathrm{Fe}$ and $\mathrm{Ni}$, respectively. The precision was evaluated in terms of relative standard deviation (\%RSD) obtained for three successive measurements of each sample.

The limits of detection (LOD) and quantification (LOQ) were calculated according to the IUPAC recommendation: $3 \times \mathrm{SD}^{\text {blank }} / \mathrm{b}$ (LOD), and $10 \times \mathrm{SD}^{\text {blank }} / \mathrm{b}$ (LOQ), where SD is the standard deviation for 10 measurements of the blank (using empty platform) and $b$ is the slope of the calibration curve.

After optimizing the calibration conditions, methods were applied to the determination of $\mathrm{Co}, \mathrm{Fe}$, and $\mathrm{Ni}$ in solar- and electronic-grade silicon samples. Aliquots of aqueous standards were manually injected onto the SSA 600 platform using micropipettes. Sample amounts in the range of $0.1-0.2 \mathrm{mg}$ were manually transferred to the graphite platforms, weighed and introduced into the atomization compartment using the automated solid sampling accessory. All measurements were

\section{TABLE II}

Factorial Design $\left(2^{3}\right)$ Used for Optimization of the Experimental Conditions

\begin{tabular}{cccl}
\hline $\begin{array}{c}\text { Experi- } \\
\text { ment* }^{*}\end{array}$ & $\begin{array}{c}\text { Pyrolysis } \\
\text { Temperature } \\
\left({ }^{\circ} \mathrm{C}\right)\end{array}$ & $\begin{array}{c}\text { Atomization } \\
\text { Temperature } \\
\left({ }^{\circ} \mathrm{C}\right)\end{array}$ & $\begin{array}{c}\text { Sample } \\
\text { Mass } \\
(\mathrm{mg})\end{array}$ \\
\hline 1 & $+\left(1600^{\mathrm{a}}, 1500^{\mathrm{b}}\right)$ & $+\left(2600^{\mathrm{a}}, 2650^{\mathrm{b}}\right)$ & $+\left(0.3-0.4^{\mathrm{a}}, 0.2-0.3^{\mathrm{b}}\right)$ \\
2 & $+\left(1600^{\mathrm{a}}, 1500^{\mathrm{b}}\right)$ & $+\left(2600^{\mathrm{a}}, 2650^{\mathrm{b}}\right)$ & $-(0.1-0.2)$ \\
3 & $+\left(1600^{\mathrm{a}}, 1500^{\mathrm{b}}\right)$ & $-\left(2400^{\mathrm{a}}, 2500^{\mathrm{b}}\right)$ & $+\left(0.3-0.4^{\mathrm{a}}, 0.2-0.3^{\mathrm{b}}\right)$ \\
4 & $+\left(1600^{\mathrm{a}}, 1500^{\mathrm{b}}\right)$ & $-\left(2400^{\mathrm{a}}, 2500^{\mathrm{b}}\right)$ & $-(0.1-0.2)$ \\
5 & $-\left(1400^{\mathrm{a}}, 1300^{\mathrm{b}}\right)$ & $+\left(2600^{\mathrm{a}}, 2650^{\mathrm{b}}\right)$ & $+\left(0.3-0.4^{\mathrm{a}}, 0.2-0.3^{\mathrm{b}}\right)$ \\
6 & $-\left(1400^{\mathrm{a}}, 1300^{\mathrm{b}}\right)$ & $+\left(2600^{\mathrm{a}}, 2650^{\mathrm{b}}\right)$ & $-(0.1-0.2)$ \\
7 & $-\left(1400^{\mathrm{a}}, 1300^{\mathrm{b}}\right)$ & $-\left(2400^{\mathrm{a}}, 2500^{\mathrm{b}}\right)$ & $+\left(0.3-0.4^{\mathrm{a}}, 0.2-0.3^{\mathrm{b}}\right)$ \\
8 & $-\left(1400^{\mathrm{a}}, 1300^{\mathrm{b}}\right)$ & $-\left(2400^{\mathrm{a}}, 2500^{\mathrm{b}}\right)$ & $-(0.1-0.2)$ \\
\hline
\end{tabular}

* $\mathrm{n}=3$.

${ }^{\mathrm{a}}$ Conditions for Co.

${ }^{\mathrm{b}}$ Conditions for $\mathrm{Fe}$ and $\mathrm{Ni}$. 
carried out in triplicate $(n=3)$, and the integrated peak absorbance was equivalent to 3 pixels.

For LS FAAS, the sample digests were properly diluted in order to adjust the measured absorbance in the linear working range. All measurements were carried out in triplicate.

\section{RESULTS AND DISCUSSION}

\section{Thermal Behavior of Analytes and Heating Program of Atomizer}

The presence of metal contaminants in solar-grade silicon and electronic-grade silicon (e.g., Co, $\mathrm{Fe}$, and $\mathrm{Ni}$ ) may reduce the efficiency of silicon chips used in most electronic equipment. First, measurements employing the most sensitive lines of the analytes showed absorbance exceeding the linear working ranges, suggesting alternative lines with lower sensitivities should be used. The line of Co at $252.136 \mathrm{~nm}$ (37\% relative sensitivity) and the lines of Fe and $\mathrm{Ni}$ at $305.909 \mathrm{~nm}$ (4\% relative sensitivity) and $305.764 \mathrm{~nm}$ (3.3\% relative sensitivity) were selected for further experiments. It should be noted that $\mathrm{Fe}$ and $\mathrm{Ni}$ were simultaneously monitored because their lines are in the same spectral win- dow of the spectrometer. Shown in Figure 1 are the spectra recorded for Co (Figure 1a) and $\mathrm{Fe}$ and $\mathrm{Ni}$ (Figure 1b) in a sample of solargrade silicon.

After selecting the suitable analytical lines, the heating program of the graphite furnace was optimized in order to maximize the matrix removal and to calibrate with aqueous standards for solid sample analysis. For the evaluation of the thermal behavior of $\mathrm{Co}, \mathrm{Fe}$, and $\mathrm{Ni}$, the maximum and minimum levels of the multivariate experiment were chosen after considering the data published in earlier publications (22-24) and using the conditions as recommended by the manufacturer.

The use of the factorial design may reduce the number of experiments required for establishing the optimum conditions in order to observe further interactions among the variables which are not possible in a univariate mode. The obtained experimental responses for each condition were used for generating a mathematical model and evaluating the influence of the variables on the absorbance signals. For the selected intervals, no significant variation in the Co absorbance was observed at the $95 \%$ confidence

\section{Atomic Apectroscopy \\ 1 Vol. 38(3), May/June 2017}

level when the pyrolysis and atomization temperatures were varied. Higher analytical signals were observed for increased sample sizes. The optimum conditions for the pyrolysis and atomization temperatures were $1600{ }^{\circ} \mathrm{C}$ and $2400{ }^{\circ} \mathrm{C}$, respectively; and for sample mass it was $0.1-0.2 \mathrm{mg}$.

For $\mathrm{Fe}$ and $\mathrm{Ni}$, the simultaneous monitoring of both elements was considered for selecting the optimum analytical signals. A significant increase on the Fe response was observed by increasing the atomization and pyrolysis temperatures, and also for the interactions: (a) pyrolysis and atomization temperatures; (b) pyrolysis temperature and sample size; (c) pyrolysis temperature, atomization temperature and sample size. Similarly to Co, no significant variation in the $\mathrm{Ni}$ absorbance was observed at the 95\% confidence level in the intervals evaluated for variables. This may be due to the more refractory characteristics of these elements in comparison to $\mathrm{Fe}$. The optimum conditions found were $1300{ }^{\circ} \mathrm{C}$ pyrolysis temperature, $2650^{\circ} \mathrm{C}$ atomization temperature, and 0.1- 0.2 mg sample size. These conditions were employed for further experiments.

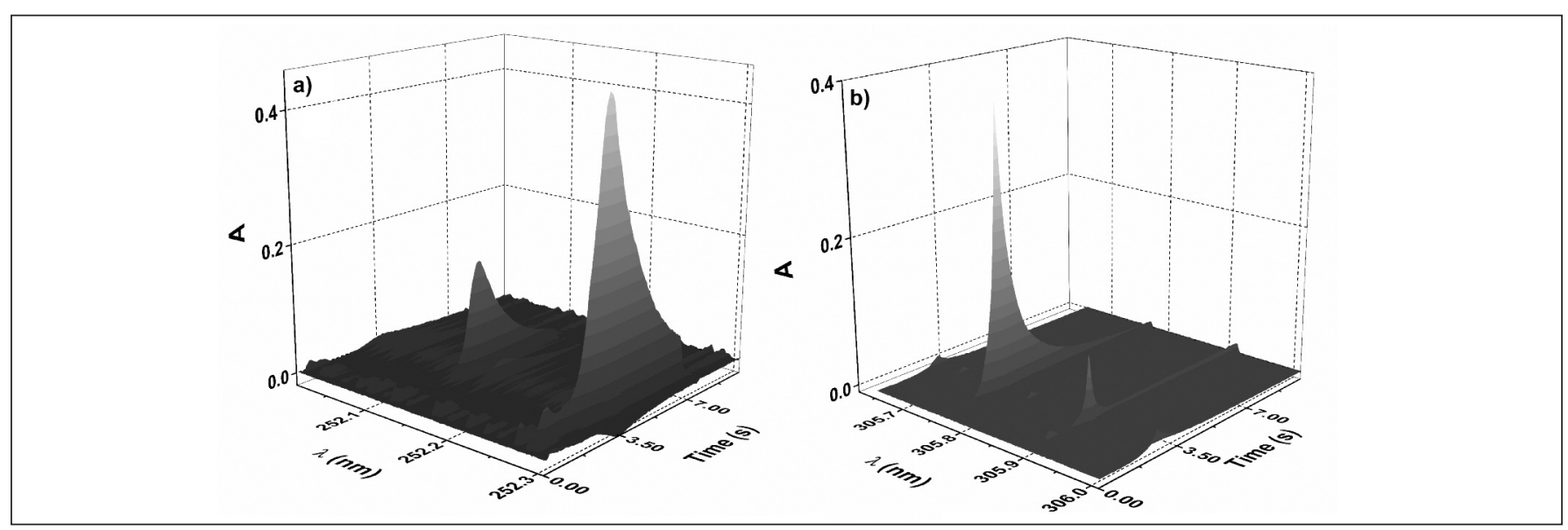

Fig. 1. Time-resolved spectra of Co in the vicinity of line at $252.136 \mathrm{~nm}$ (a) and (b) $\mathrm{Ni}(305.909 \mathrm{~nm})$ and Fe (305.760 $\mathrm{nm}$ ) lines in SoG-Si. 


\section{Matrix Effects}

Matrix effects were evaluated by comparing the slopes of the calibration curves (0.0-2.0 ng Co, 0.0 - $15.0 \mathrm{ng} \mathrm{Fe}$, and 0.0-3.5 ng Ni) built up in aqueous solution and solid media (SoG-Si). For this sequence, good linear correlation coefficients (r) were obtained for Co (0.9999, 0.9968), Fe (0.9959, $0.9967)$, and for $\mathrm{Ni}(0.9977$, 0.9955); and the slopes of the analytical curves were 0.22745 , 0.21372 (Co), $0.03791,0.03812$ (Fe), and 0.0217 and $0.0206(\mathrm{Ni})$ for aqueous and solid calibration, respectively. These data expect errors of $<6.0 \%, 1.6 \%$, and $5.3 \%$ for $\mathrm{Co}, \mathrm{Fe}$, and $\mathrm{Ni}$, respectively, when aqueous standard calibration is used for analysis of the solid samples. The characteristic masses calculated for aqueous and solid media, respectively, were 0.0195 pg and $0.0199 \mathrm{pg}$ (Co); 0.094 pg and $0.086 \mathrm{pg}(\mathrm{Fe})$, and $0.53 \mathrm{pg}$ and $0.54 \mathrm{pg}(\mathrm{Ni})$. Matrix matching or analyte addition calibrations would minimize matrix effects. However, taking into consideration that errors of $<6 \%$ are acceptable for solid sample analysis, aqueous calibration is straightforward and was adopted for further studies.

\section{Analytical Performance}

The main figures of merit relating to the direct determination of $\mathrm{Co}, \mathrm{Fe}$, and $\mathrm{Ni}$ in solar- and electronic-grade silicon were evaluated. A $0.10-0.20 \mathrm{mg}$ quantity of sample was weighed and assayed. The calculated characteristic masses calculated for aqueous and solid media were $0.0195 \mathrm{pg}$ and $0.0199 \mathrm{pg}$ (Co); $0.094 \mathrm{pg}$ and $0.086 \mathrm{pg}$ (Fe), and $0.53 \mathrm{pg}$ and $0.54 \mathrm{pg}(\mathrm{Ni})$. The limit of detection, calculated according to IUPAC recommendation, was $0.39 \mathrm{mg} \mathrm{kg}^{-1}, 1.14 \mathrm{mg} \mathrm{kg-}^{1}$, and $5.71 \mathrm{mg} \mathrm{kg}^{-1}$ for $\mathrm{Co}, \mathrm{Fe}$, and $\mathrm{Ni}$, respectively. For comparison purposes, the samples were digested and analyzed by LS FAAS. The values for $\mathrm{Co}, \mathrm{Fe}$, and Ni obtained by both techniques (Table III) were in agreement at the $95 \%$ confidence level (paired $t$-test). Also, accuracy was checked by addition/recovery tests. Cobalt, Fe, and Ni were determined in high-purity silica spiked with 3.3 and $6.6 \mathrm{mg} \mathrm{kg}^{-1} \mathrm{Co}, 20$ and $33 \mathrm{mg} \mathrm{kg}^{-1} \mathrm{Fe}$ and Ni. Recoveries were in the range of $94-97 \%(\mathrm{Co})$, 87-109\% (Fe), and 88-99\% (Ni). The found values were in agreement with the spike values for Co, $\mathrm{Fe}$, and $\mathrm{Ni}$ at the $95 \%$ confidence level. The method was then applied for $\mathrm{Co}, \mathrm{Fe}$, and $\mathrm{Ni}$ determination in solar- and electronic-grade silicon samples. The analysis of the samples showed concentrations in the range of $7.8-16.5 \mathrm{mg} \mathrm{kg}^{-1}$ for $\mathrm{Co}$, 28.0-36.2 $\mathrm{mg} \mathrm{kg}^{-1}$ for $\mathrm{Fe}$, and 228-355 $\mathrm{mg} \mathrm{kg}^{-1}$ for Ni. The relative standard deviation $(n=12)$ for a sample containing $7.80 \mathrm{mg} \mathrm{kg}^{-1}$ Co, $36.2 \mathrm{mg} \mathrm{kg}^{-1} \mathrm{Fe}$, and 228.5 $\mathrm{mg} \mathrm{kg}^{-1} \mathrm{Ni}$ was $6.4 \%$ for $\mathrm{Co}, 6.1 \%$ for $\mathrm{Fe}$, and $1.0 \%$ for $\mathrm{Ni}$. The main figures of merit for the determination of $\mathrm{Co}, \mathrm{Fe}$, and $\mathrm{Ni}$ in pure silicon by the proposed SS HR-CS GFAAS methods are depicted in Table IV.

\section{TABLE III}

Results (mean \pm standard deviation) for Co, Fe, and $\mathrm{Ni}\left(\mathrm{mg} \mathrm{kg}^{-1}\right)$ Determined $(n=3)$ in SoG-Si and EG-Si by Proposed DSS HR-CS GFAAS and LS FAAS Comparatve Technique

\begin{tabular}{ccccc}
\hline Analyte & \multicolumn{2}{c}{ SoG-Si } & \multicolumn{2}{c}{ EG-Si } \\
& DSS HR-CS & LS & DSS HR-CS & LS \\
& GFAAS & FAAS & GFAAS & FAAS \\
\hline Co & $7.80 \pm 0.50$ & $8.58 \pm 0.62$ & $16.5 \pm 1.2$ & $16.4 \pm 1.3$ \\
Fe & $36.2 \pm 2.2$ & $37.9 \pm 1.9$ & $28.0 \pm 2.7$ & $27.5 \pm 0.8$ \\
$\mathrm{Ni}$ & $228.5 \pm 2.2$ & $233.7 \pm 5.9$ & $355.0 \pm 28.8$ & $329.1 \pm 23.0$ \\
\hline
\end{tabular}

TABLE IV

Main Figures of Merit for the Determination of Co, Fe, and Ni in Pure Silicon by Proposed Method Based on DSS HR-CS GFAAS

\begin{tabular}{|c|c|c|c|}
\hline Parameters & $\mathrm{Co}$ & $\mathrm{Fe}$ & $\mathrm{Ni}$ \\
\hline $\operatorname{LOD}\left(\mathrm{mg} \mathrm{kg}^{-1}\right)$ & 0.39 & 1.14 & 5.71 \\
\hline LOQ (mg kg-1) & 1.30 & 3.80 & 19.0 \\
\hline $\mathrm{m}_{0}(\mathrm{pg})$ & $\begin{array}{l}0.0195 \text { (aqueous); } \\
0.0199 \text { (solid) }\end{array}$ & $\begin{array}{l}0.094 \text { (aqueous); } \\
0.086 \text { (solid) }\end{array}$ & $\begin{array}{l}0.53 \text { (aqueous); } \\
0.54 \text { (solid) }\end{array}$ \\
\hline RSD (\%) & 6.0 & 1.6 & 5.3 \\
\hline$b$ & $\begin{array}{l}0.22745 \text { (aqueous); } \\
0.21372 \text { (solid) }\end{array}$ & $\begin{array}{l}0.03791 \text { (aqueous); } \\
0.03812 \text { (solid) }\end{array}$ & $\begin{array}{l}0.0217 \text { (aqueous); } \\
0.0206 \text { (solid) }\end{array}$ \\
\hline $\mathrm{r}$ & $\begin{array}{l}0.9999 \text { (aqueous); } \\
0.9968 \text { (solid) }\end{array}$ & $\begin{array}{l}0.9959 \text { (aqueous); } \\
0.9967 \text { (solid) }\end{array}$ & $\begin{array}{l}0.9977 \text { (aqueous); } \\
0.9955 \text { (solid) }\end{array}$ \\
\hline $\begin{array}{l}\text { Pyrolysis } \\
\text { Temperature }\left({ }^{\circ} \mathrm{C}\right)\end{array}$ & 1600 & 1300 & 1300 \\
\hline $\begin{array}{l}\text { Atomization } \\
\text { Temperature }\left({ }^{\circ} \mathrm{C}\right)\end{array}$ & 2400 & 2650 & 2650 \\
\hline Sample Mass (mg) & $0.1-0.2$ & $0.1-0.2$ & $0.1-0.2$ \\
\hline Modifier & No & No & No \\
\hline
\end{tabular}

LOD: limit of detection; LOQ: limit of quantification; $\mathrm{m}_{0}$ : characteristic mass; RSD: relative standard derivation; b: slope; r: correlation coefficient. 


\section{CONCLUSION}

The determination of contaminants in a silicon matrix is an analytical challenge due to the difficulties and complexities of sample preparation. The heating program and sample size were optimized by using a factorial design which reduces the number of experiments and enables the consideration of interactions between the variables. Sample concentrations ranged between 7.8-16.5 $\mathrm{mg} \mathrm{kg}^{-1}$ (Co); 28.0-36.2 $\mathrm{mg} \mathrm{kg}^{-1}$ (Fe), and 228-355 $\mathrm{mg} \mathrm{kg}^{-1}$ (Ni). Cobalt, Fe, and Ni were precisely and accurately determined. The employment of HR-CS GFAAS combined with solid sampling allows the determination of the analytes in high-purity silicon without any previous sample preparation and addition of reagents.

\section{ACKNOWLEDGMENT}

The authors would like to thank the Fundação de Amparo à Pesquisa do Estado de São Paulo for financial support of this work (Grant \#2014/12595-1). The authors are also grateful to the Coordenação de Aperfeiçoamento de Pessoal de Nível Superior (CAPES) for fellowships to D.V.B. and to the Conselho Nacional de Desenvolvimento Científico e Tecnológico (CNPq) for fellowships to A.I.B. and M.A.B., and researchship to J.A.G.N.

Received Novemvee 7, 2016.

\section{REFERENCES}

1. K.H. Solangi, M.R. Islam, R. Saidur, N.A. Rahim, H. Fayaz, Renew. Sustain. Energy Rev. 15, 2149 (2011).

2. G.R. Timilsina, L. Kurdgelashvili, P.A. Narbel, Renew. Sustain. Energy Rev. 16, 449 (2012).

3. M. Hystad, C. Modanese, M. Di Sabatino, L. Arnberg, Sol. Energy Mater. Sol. Cells 103, 140 (2012).

4. Y. Delannoy, J. Cryst. Growth 7 ,
360 (2012).

5. G. Coletti, P.C.P. Bronsveld, G. Hahn, W. Warta, D. Macdonald, B. Ceccaroli, Adv. Funct. Mater. 21, 879 (2011).

6. S. Meyer, S. Wahl, A. Molchanov, K. Neckermann, C. Moller, K. Lauer, Sol. Energy Mater. Sol. Cells 130, 668 (2014).

7. G. Kolosovska, A. Viksna, G. Chikvaidze, A. Osite, A. Opalais, Mater. Sci. Eng. 38, 1 (2012).

8. C. Bendicho, I. Lavilla, F. PenaPereira, V. Romero, J. Anal. At. Spectrom. 27, 1831 (2012).

9. J. Rip, K. Wostyn, P. Mertens, S. De Gendt, M. Claes, Energy Proced. 27, 154 (2012).

10. S. Darwiche, M. Benmansour, N. Eliezer, D. Morvan, Prog Photovoltaics Res. Appl. 20, 463 (2012).

11. M. Di Sabatino, A.L. Dons, J. Hinrichs, L. Arnberg, Spectrochim. Acta Part B 66, 144 (2011).

12. J. Hampel, F.M. Boldt, H. Gerstenberg, G. Hampel, J.V. Kratz, S. Reber, Appl. Radiat. Isto. 69, 1365 (2011).

13. P. Peres, A. Merkulov, F. Desse, $M$ .Schuhmacher, Surf. Interface Anal. 43, 643 (2011).

14. P.L. Buldini, A. Mevoli, J.L. Sharma, Talanta 47, 203 (1998).

15. M.A. Belarra, M. Resano, F. Vanhaecke, L. Moens, TrAC Trends Anal. Chem. 21, 828 (2002).

16. B. Welz, Anal. Bioanal. Chem. 381, 69 (2005).

17. M. Resano, M. Aramendía, M.A. Belarra, J. Anal. At. Spectrom. 29, 2229 (2014).

18. A.T. Duarte, M.B. Dessuy, M.G.R. Vale, B. Welz, Anal. Methods 5, 6941 (2013).

19. S. Kelestemur, M. Özcan, Microchem. J. 118, 55 (2015).

20. A.F. da Silva, D.L.G. Borges, F.G. Lepri, B. Welz, A.J. Curtius, U. Heitmann, Anal. Bioanal. Chem. 382, 1835 (2005).

21 M. Resano, M.D.R. Flórez, I. Queralt, E. Marguí, Spectrochim. Acta Part B 105, 38 (2015).

22. B. Gómez-Nieto, M.J. Gismera,

\section{A Stomic $_{\text {vol. } 38(3), \text { May/yne } 2017}^{\text {tol }}$}

M.T. Sevilla, J.R. Procopio, Talanta 116, 860 (2013)

23. M. Resano, E. Bolea-Fernández, E. Mozas, M.R. Flórez, P. Grinberg, R.E. Sturgeon, J. Anal. At. Spectrom. 28, 657 (2013).

24. A.S. Ribeiro, M.A. Vieira, A.F. da Silva, D.L.G. Borges, B. Welz, U. Heitmann, Spectrochim. Acta Part B 60, 693 (2005). 